\title{
PENGARUH SUPERVISI KEPALA SEKOLAH, PELATIHAN, DAN SELF EFFICACY GURU BIMBINGAN KONSELING SMA KOTA PEKANBARU
}

\author{
Arfiyanti Agustina 1) \\ Gimin ${ }^{2)}$ \\ Rr. Sri Kartikowati ${ }^{3)}$ \\ 1) Guru Bimbingan Konseling SMA Cendana Pekanbaru \\ 2) Lecturer of Education Management Study Programme PPS University of Riau \\ 3) Lecturer of Education Management Study Programme PPs University of Riau \\ Email: arficendana@gmail.com
}

\begin{abstract}
This study aims to determine how much influence (1) the supervision of the principal on the performance of counseling guidance teachers, (2) training on the performance of counseling guidance teachers, (3) self-efficacy on the performance of counseling guidance teachers, and (4) principal supervision, training, and self-efficacy together on the performance of counseling teachers in SMA Kota Pekanbaru. This research is a quantitative study with a sampling technique. Sampling from members of the population at random using random sampling techniques. The sample number is 71 teachers. The data analysis used was descriptive analysis, infrential statistical analysis, and hypothesis testing. The results showed that there was a significant effect: (1) supervision of the principal on teacher performance by 40.7\%, (2) training on teacher performance by $38.9 \%$, (3) self-efficacy on teacher performance by $57.7 \%$, (4) principal supervision, training and self-efficacy on teacher performance by $28.5 \%$. The self-efficacy variable provides the largest effective contribution among the three independent variables on the performance of the SMA Kota Pekanbaru counseling teacher. This means that the performance of counseling teachers in SMA Kota Pekanbaru can be influenced by the supervision of the principal, training, and self-efficacy.
\end{abstract}

Keywords: Principal Supervision; Training; Self Efficacy; Teacher Performance 
ABSTRAK
Penelitian ini bertujuan untuk mengetahui seberapa besar pengaruh (1) supervisi kepala sekolah terhadap kinerja guru bimbingan konseling, (2) pelatihan terhadap kinerja guru bimbingan konseling, (3) self efficacy terhadap kinerja guru bimbingan konseling, dan (4) supervisi kepala sekolah, pelatihan, dan self efficacy secara bersama-sama terhadap kinerja guru bimbingan konseling SMA Kota Pekanbaru. Penelitian ini merupakan penelitian kuantitatif dengan teknik sampling. Pengambilan sampel dari anggota populasi secara acak dengan menggunakan teknik sampling random. Jumah sampel berjumlah 71 orang guru. Analisis data yang digunakan yaitu analisis deskriptif, analisis statistik infrensial dan pengujian hioptesis. Hasil penelitian menunjukkan bahwa terdapat pengaruh yang signifikan : (1) supervisi kepala sekolah terhadap kinerja guru sebesar 40,7\%, (2) pelatihan terhadap kinerja guru sebesar 38,9\%, (3) self efficacy terhadap kinerja guru sebesar 57,7\%, (4) supervisi kepala sekolah, pelatihan dan self efficacy terhadap kinerja guru sebesar 28,5\%. Variabel self efficacy memberikan sumbangan efektif terbesar di antara ketiga variabel bebas tersebut terhadap kinerja guru bimbingan konseling SMA Kota Pekanbaru. Hal ini berarti bahwa baik tidaknya kinerja guru bimbingan konseling SMA Kota pekanbaru dapat dipengaruhi oleh supervisi kepala sekolah, pelatihan, dan self efficacy.

Kata Kunci: Supervisi Kepala Sekolah; Pelatihan; Self-Efficacy; Kinerja Guru

\section{PENDAHULUAN}

Proses pendidikan bisa didapatkan sumber daya manusia yang berkualitas, karena pendidikan merupakan faktor utama dalam membangun manusia berkualitas. Pendidikan merupakan proses pengubah sikap dan tingkah laku seseorang atau kelompok dalam usaha mendewasakan manusia melalui prosen pembelajaran

Berbagai upaya telah diakukan pemerintah untuk meningkatkan mutu pendidikan. salah satu upaya yang dilakukan pemerintah berkaitan dengan peningkatan kualitas guru adalah adanya UU no 14 Tahun 2005 tentang guru dan dosen dan Peraturan Pemerintah No. 19 Taun 2005 tentang Standar Nasional Pendidikan. Guru mrupakan kunci keberhasilan mutu pendidikan. sebagai tenaga professional guru juga memerlukan pengawasan serta bimbingan demi memperbaiki pelaksanaan proses belajar mengajar yang telah mereka lakukan selama ini. Tidak hanya guru mata pelajaran saja tetapi guru bimbingan konseling juga mempunyai peran dalam membimbing para peserta didik.

Seorang guru perlu dilakukan penilaian atas pekerjaannya. Penilaian prestasi kerja merupakan salah satu proses yang dilakukan dalam mengevaluasi kemampuan kinerja guru. Penilaian tersebut dimaksudkan untuk mengetahui perkembangan kualitas guru, hasil penilaian kinerja dapat diketahui kelebihan dan kekurangan dari pekerjaan tersebut

Kinerja guru dapat diartikan sebagai suatu kondisi yang menunjukkan kemampuan seorang guru dalam menjalankan tugasnya di sekolah serta menggambarkan adanya suatu perbuatan yang ditampilkan guru selama meakukan aktivitas pembelajaran. Kinerja guru tidak hanya ditunjukkan oleh hasil kerja, akan 
tetapi juga ditunjukkan oleh perilaku dalam bekerja. Kinerja guru yang di nilai tidak hanya guru mata pelajaran saja melainkan ada guru bimbingan dan konseling yang juga merupakan bagian dari tenaga pendidikan.

Bimbingan dan konseling merupakan saah satu bagian yang tidak terpisahkan dengan komponen pendidikan, dan sangat berperan dalam rangka mencapai tujuan pendidikan. sebagai salah satu unsur pendidikan, layanan bimbingan dan konseling untuk mengembangkan kepribadiannya dimasa yang akan datang. Kegiatan bimbingan dan konseling di sekolah, diselenggarakan oleh pejabat fungsional yang secara resmi dinamakan guru Bimbingan Komseling atau konselor.

Pada kenyataannya, guru BK masih dihadapkan pada kritikan-kritikan, baik sebagai wujud kekecewaan atas kinerja guru BK di sekolah maupun sebagai wujud kepedulian masyarakat akan bimbingan dan konseling. Permasalahan guru BK dilapangan juga banyaknya guru Bimbingan Konseling yang tidak berlatar belakang program studi Bimbingan dan Konseling atau yang sudah mengikuti program pelatihan guru Bimbingan dan Konseling dari yang bukan berlatar belakang Bimbingan dan Konseling. Tetapi ada dari guru mata pelajaran yang tidak memiliki jam mengajar dikarenakan guru mata pelajaran tersebut sudah terlalu banyak sehingga dijadikan guru Bimbingan Konseling.

Masih adanya yang beranggapan bahwa guru Bimbingan Konseling adalah satpam sekolah yang hanya memarahi siswa jika terlambat masuk dan keliling mencari siswa yang cabut. Peraturan Menteri Pendidikan Nasional no 111 tahun 2014 dijelaskan bahwa guru Bimbingan Konseling mendapat jam mengajar sebanyak 1 jam setiap minggu perkelas. Tetapi kenyataan dilapangan banyak sekali yang tidak mendapatkan jam masuk kelas. 1 (satu) guru Bimbingan Konseling ideal nya 150-160 siswa bimbingan nya, yang terjadi 1 (satu) guru Bimbingan Konseling membimbing lebih dari 300 orang. Hal seperti ini menjadi sangat tidak efektif. Sehingga pelayanan yang diberikan hanya bersifat insidentil tidak terprogram. Dan yang diberikan layanan hanya siswa yang berkasus atau yang berprestasi saja sedangkan selain siswa-siswa tersebut dianggap siswa tidak bermasalah dan bisa menyelesaikan masalahnya sendiri.

Peran kepala sekolah sebagai supervisor diharapkan dapat meningkatkan kinerja guru di sekolah. Melalui kemampuan kepala sekolah dalam melaksanakan kegiatan supervisi yang terdiri dari supervisi perencanaan pembelajaran, pelaksanaan pembelajaran, penilaian pembelajaran yang terdiri dari kegiatan remedial dan kegiatan pengayaan, diharapkan dapat berpengaruh terhadap kinerja guru. Hingga saat ini masih terdapat guru-guru yang kebingungan dalam membuat perangkat pembelajaran atau perencanaan pembelajaran. Masih banyak guru yang mengcopy-paste perangkat pembelajaran yang dibuat di Musyawarah Guru Bimbingan Konseling (MGBK) maupun di Musyawarah Guru Mata Pelajaran (MGMP). Dalam hal ini perangkat pembelajaran belum disesuaikan dengan kebutuhan sekolah masing-masing.

Pelaksanaan supervisi yang dilaksanakan kepala sekolah perlu dimaksimalkan sehingga dapat memberikan kontribusi yang memadai untuk meningkatkan mutu layanan belajar, dengan tidak mengesampingkan pada hal-hal berikut yaitu beban kerja 
kepala sekolah terlalu berat dan latar belakang pendidikan mereka kurang sesuai dengan bidang studi yang disupervisi. Hal lain yang menjadi kendala adalah kepala sekolah hanya menekankan pada bidang administrasi nya saja. Sehingga tidak ada perbaikan untuk guru kedepannya.

Kinerja guru juga dipengaruhi oleh pelatihan yang diikutinya. Berdasarkan hasil wawancara dengan beberapa guru Bimbingan Konseling SMA rata-rata mereka mengikuti pelatihan hanya $1 \mathrm{kali}$ dalam 1 tahun bahkan ada yang sama sekali tidak mengikuti pelatihan dalam 3 tahun. Hal ini menjadi kendala dalam meningkatkan kinerja para guru Bimbingan Konseling SMA. Sedikitnya pelatihan yang dilakukan baik itu dari pemerintahan atau non pemerintahan, sehingga sedikitnya jumlah pelatihan yang diikuti oleh guru Bimbingan Konseling SMA tersebut.

Dengan sedikitnya pelatihan yang diikuti guru-guru tersebut self efficacy atau keyakinan diri guru tersebut menjadi rendah. Banyak guru yang tidak yakin dengan kemampuan diri yang mereka punya. Banyak juga dari guru-guru Bimbingan Konseling ini yang tidak ikut dalam kegiatan rutin Musyawarah Guru Bimbingan Konseling (MGBK) yang diadakan dua minggu sekali. Kegiatan ini didukung oleh Dinas Pendidikan Provinsi Riau dan P4TK Penjas dan BK. Dalam MBGK banyak hal yang di bahas disetiap pertemuannya. Mulai dari pembuatan perangkat, praktek konseling dan sosialisasi Perguruan Tinggi. Terkadang tidak hadirnya dalam pertemuan rutin MGBK dikarenakan tidak ada dukungan dari kepala sekolah, sehingga tidak diberikan izin untuk hadir dikegiatan tersebut. Kepala sekolah tidak ingin keluar di jam kerja selain hari sabtu dilaksanakan nya. Sehingga ada beberapa sekolah yang tidak hadir dalam kegiatan ini. Walaupun surat sudah kita lampirkan beserta jadwal kegiatan MGBK selama satu tahun atau dua semester.

Melihat permasalahanpermasalahan diatas maka sangat perlu penelitian ini dilakukan dan peneliti akan mencoba menganalisis pengaruh supervisi kepala sekolah, pelatihan dan self efficacy terhadap kinerja guru bimbingan konseling SMA kota Pekanbaru. Tujuan penelitian ini adalah untuk menganalisis 1) pengaruh supervisi kepala sekolah terhadap kinerja guru bimbingan konseling SMA kota Pekanbaru, 2) pengaruh pelatihan terhadap kinerja guru bimbingan konseling SMA kota Pekanbaru, 3) pengaruh self efficacy terhadap kinerja guru bimbingan konseling SMA kota Pekanbaru, 4) pengaruh supervisi kepala sekolah, pelatihan, dan self efficacy terhadap kinerja guru bimbingan konseling SMA Kota Pekanbaru.

\section{KAJIAN TEORETIS}

\section{Kinerja Guru}

Guru Bimbingan Konseling juga sangat berperan aktif dalam membina dan mendidik peserta didik di sekolah. Guru Bimbingan Konseling harus menjadi pendengar yang baik untuk para peserta didik. Yang di tangani guru Bimbingan dan Konseling tidak hanya peserta didik yang bermasalah saja tetapi peserta didik yang membutuhkan informasi tentang belajar dan karir. Banyak hal yang bisa di diskusikan bersama Guru Bimbingan Konseling.

Kinerja bisa diartikan sebagai hasil kerja seseorang. Seperti yang di uangkapkan Rivai (2006:14) kinerja merupakan terjemahan dari kata 
performance yang didefinisikan sebagai hasil atau tingkat keberhasilan seseorang secara keseluruhan dalam proses jangka waktu tertentu selama mlaksanakan pekerjaannya dibandingkan dalam mencapai standar hasil kerja, target atau sasaran ada criteria yang telah ditentukan dan disepakati bersama.

Sedangkan menurut Nawawi (2005:234) memberikan pengertian kinerja sebagai hasil kerja. Yang mana pengertian tersebut memberikan pemahaman bahwa kinerja merupakan suatu perilaku atau perbuatan seseorang yang secara langsung ataupun tidak langsung dapat diamati oleh orang lain.

Menurut Supardi (2016:47) menyatakan kinerja merupakan hasil kerja yang telah dicapai oleh seseorang berdasarkan standarisasi dan waktu yang disesuaikan dengan jenis pekerjaan berdasarkan norma dan etika yang telah ditetapkan oleh organisasi.

Dengan demikian guru adalah seorang pendidik yang tidak hanya mengajar saja tetapi juga membimbing dan megarahkan peserta didik. Seorang peserta didik tidak hanya mempunyai ilmu tetapi juga mempunyai akhlak, sopan santun dan beradab. Sehingga siswa itu berguna dan dapat diterima hidup di tengah masyarakat. Guru juga merupakan pekerjaan professional artinya bahwa guru mempunyai ilmu pengetahuan, dan mampu dalam mengajar dan mendidik seduai dengan bidang ajarnya sehingga peserta didik mempunyai peningkatan dalam kualitas sumber daya manusia nya.

\section{Supervisi Kepala Sekolah}

$\begin{array}{lr}\text { Supervisi adalah aktivitas } \\ \text { menentukan kondisi-kondisi/ } & \text { syarat- } \\ \text { syarat yang esensial, yang akan menjamin }\end{array}$

tercapainya tujuan-tujuan pendidikan. sehingga supervisi mempunyai pengertian yang luas. Supervisi ini berupa dorongan, bimbingan, dan kesempatan bagi pertumbuhan kealian dan kecakapan guru-guru, seperti bimbingan dalam usaha dan pelaksanaan pembahauanpembaharuan dalam pendidikan dan pengajaran, pemilihan alat-alat pelajaran dan metode-metode mengajar yang lebih baik, cara-cara penilaian yang sistematika terhadap fase seluruh proses pengajaran.

Menurut Ngalim (2019:76)

supervisi adalah suatu aktivitas pembinaan yang direncanakan untuk membantu para guru dan pegawai sekolah lainnya dalam melakukan pekerjaan mereka secara efektif.

Nealey dan Evans dalam bukunya, "Hand-books for Effective Supervision of Instruction", seperti berikut: “... the team 'supervision' is used to describe those activities which are primarily and directly concernd with studying and improving the conditions which surround the learning and growth of pupils and teachers. "(Ngalim, 2019:76)

“... Tim pengawas berfungsi untuk menggambarkan kegiatan2 tersebut secara langsung dan paling utama yg berhubungan tentang penelitian dan peningkatan kondisi yang berhubungan dengan pembelajaran dan perkembangan anatra murid dan guru."

Burton dalam bukunya, "Supervision a Social Process", sebagai berikut: "Supervisi is an expert technical service primarily aimed at studying and improving co-operatively all factors which ffect child growth and development".(Ngalim, 2019:77).

Burton dalam bukunya. "Supervisi adalah sebuah proses sosial". Sebagai berikut: "pengawasan adalah pekerjaan seorang ahli, terutama yang ditujukan untuk 
mempelajari dan meningkatkan secara kooperatif terhadap semua faktor-faktor yang mempengaruhi perkembangan dan pertumbuhan anak."

\section{Pelatihan}

Pelatihan adalah sebuah konsep manajemen sumber daya manusia yang melibatkan aktivitas-aktivitas pemberian instruksi-instruksi khusus yang direncanakan. Pelatihan merupakan serangkaian aktivitas individu dalam meningkatkan keahlian dan pengetahuan secara sistematis sehingga mampu memiliki kinerja yang professional dibidangnya. (Widodo, 2015:82)

Menurut Rivai dan Sagala (2011:212), pelatihan adalah proses secara sistematis mengubah tingkah laku pegawai untuk mencapai tujuan organisasi. Pelatihan berkaitan dengan keahlian dan kemampuan pegawai untuk melaksanakan pekerjaan saat ini. Jusmaliani (2011:99), mengungkapkan pelatihan adalah proses melatih karyawan baru atau karyawan yang akan memperoleh penempatan baru dengan keterampilan dasar yang diperlukannya untuk melaksanakan pekerjaan.

Dari beberapa pendapat para ahli dapat di simpulkan, pelatihan adalah proses aktivitas untuk meningkatkan keahlian dan kompetensi karyawan dalam melaksanakan pekerjaan yang efektif dan efisien sehingga menjadi professional di bidang nya.

\section{Self Efficacy}

Salah satu aspek pengetahuan tentang diri yang paling berpengaruh dalam kehidupan manusia sehari-hari disebut dengan Self efficacy atau Efikasi Diri. Menurut Bandura (1997), adalah persepsi seseorang akan kemampuan yang dimilikinya untuk mencapai suatu tujun tertentu.

Menurut Bandura dan Wood (1997)

Self efficacy sebagai :

"belief in one's capabilities to mobilize the motivation, cognitive resources, and courses of acton need to meet given situasional demand".

Self efficacy adalah kemampuan seseorang untuk menggerakkan motivasi, sumber-sumber kognitif, dan serangkaian tindakan yang diperlukan untuk memenuhi tuntutan-tuntutan dari situasi yang dihadapi. Bandura, membedakan komponen self efficacy yang terdiri dari efficacy expectations dan outcome expectations. Efficacy expectations adalah keyakinan diri seseorang bahwa dirinya dapat berhasil melakukan perilaku yang ingin dilakukan. Sementara outcome expectations menentukan seberapa besar seseorang mencoba dan seberapa lama akan bertahan pada perilaku tersebut. Self efficacy mengacu pada keyakinan sejauh mana individu memperkirakan kemampuan dirinya dalam melakukan tugas atau melakukan suatu tugas yang diperlukan untuk mencapai suatu hasil tertentu.

Woolfolk dalam Gerson Salomo kolondam (2018:5) menjelaskan secara umum Self Efficacy adalah penilaian seseorang terhadap dirinya sendiri atau tingkat keyakinan tentang seberapa besar kemampuannya dalam mengerjakan suatu tugas yang dilaksanakannya yang bertujuan untuk mencapai hasil tertentu yang akan dicapainya.

Bandura dalam Leni Oktavia (2018:5) menjelaskan bahwadimensi self efficacy terdiri dari tiga dimensi yaitu : 1) Magnitude atau tingkat kesulitan tugas, mengacu pada taraf kesulitan tugas yang diyakini akan mampu mengatasinya, tingkat efikasi diri individu berbeda satu 
dengan yang lain, tingkatan kesulitan dari sebuah tugas apakah sulit atau mudah akan menentukan efikasi-diri. Jika tidak terdapat suatu halangan yang berarti untuk di atas, maka tugas tersebut akan sangat mudah dilakukan dan semua orang mempunyai efikasi diri yang tinggi. 2) Generality atau luas bidang perilaku, mengacu pada variasi situasi dimana penilaian tentang keyakinan diri ditetapkan. Individu dapat menilai dirinya memiliki efikasi pada banyak aktivitas atau pada aktivitas tertentu saja. Dengan semakin banyak keyakinan diri yang dapat diterapkan pada berbagai kondisi makan semakin tinggi efikasi diri individu.3) Strenght atau kemantapan keyakinan, dimensi kemantapan keyakinan merupakan dimensi yang berhubungan dengan tingkat kekuatan dan kelemahan keyakinan tentang kompetensi yang di persepsikan. Dimensi ini mencangkup pada derajat kemantapan individu terhadap keyakinan berhadapan dengan tuntutan tugas atau suatu permasalahan. Kemantapan inilah yang menentukan ketahanan dan keuletan individu dalam menghadapi suatu permasalahan.

\section{METODOLOGI PENELITIAN}

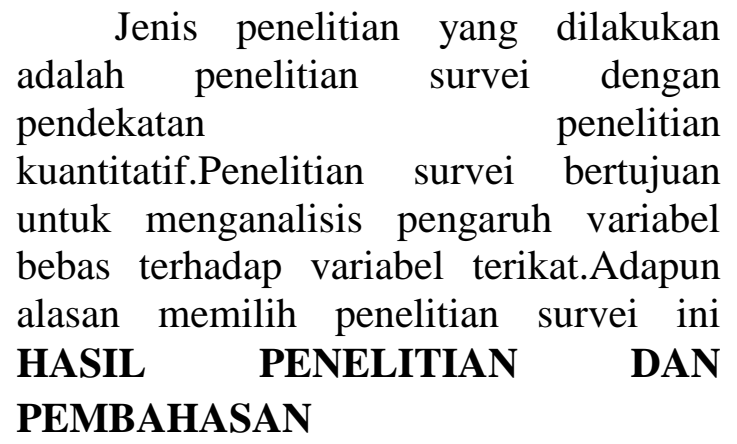

\section{Pengujian Persyaratan Analisis}

\section{a. Uji Normalitas}

Pada kolom Kolmogorov-Smirnov, diperoleh nilai signifikansi variabel adalah untuk melihat seberapa besar pengaruh variabel bebas terhadap variabel terikat.Variabel bebas dalam penelitian ini adalah supervisi kepala sekolah (X1), pelatihan (X2), dan self efficacy (X3) sedangkan variabel terikat adalah Kinerja guru (Y). Penelitian ini dilakukan di kota Pekanbaru dengan objek penelitian guruguru bimbingan konseling SMA negeri dan swasta dengan jumlah populasi sebanyak 85 orang.Sedangkan ukuran sampel dihitung dengan menggunakan rumus Slovin dengan tingkat kesalahan 5\% sehingga diperoleh sebanyak 71 orang, dengan teknik simple random sampling.

Instrumen yang digunakan dalam penelitian ini merupakan instrumen yang dikembangkan dan dibuat sendiri oleh peneliti dengan tahapan, yaitu: 1) menyusun variabel penelitian, 2) menyusun kisi-kisi instrumen, 3) validasi instrument, 4) melakukan uji coba instrumen dengan melakukan pengujian validitas dan reabilitas instrumen.

Teknik analisis data yaitu dengan menggunakan gabungan antara statistik deskriptif dengan statistik inferensial.Statistik deskriptif berguna untuk mendeskripsikan demografi dari masing-masing variabel penelitian. Inferensial digunakan untuk menguji hipotesis penelitian dengan menggunakan analisa regresi yang di dahului dengan: 1) Uji normalitas, 2) Uji linieritas, 3) Uji multikolinieritas.

supervisi kepala sekolah $\left(\mathrm{X}_{1}\right)$ sebesar 0,067, nilai signifikansi variabel pelatihan $\left(\mathrm{X}_{2}\right)$ sebesar 0,174 , nilai signifikansi variabel self efficacy $\left(\mathrm{X}_{3}\right)$ sebesar 0,200 serta nilai signifikansi variabel kinerja guru (Y) sebesar 0,200. Nilai signifikansi 
dari masing-masing variabel lebih besar dari 0,05. Dengan demikian dapat disimpulkan bahwa ketiga variabel penelitian berdistribusi normal

\section{b. Uji Linieritas}

Diperoleh nilai signifikansi (sig) deviation from linearity supervisi kepala sekolah (X1) dengan kinerja guru (Y) adalah 0,205, nilai ini lebih besar dari 0,05 . Maka dapat disimpulkan bahwa adanya hubungan yang linear secara signifikan antara variabel supervisi kepala sekolah (X1) dengan variabel kinerja guru (Y). Selanjutnya diperoleh nilai signifikansi (sig) deviation from linearity pelatihan (X2) dengan kinerja guru (Y) adalah 0,735 , nilai ini lebih besar dari 0,05 . Maka dapat disimpulkan bahwa adanya hubungan yang linear secara signifikan antara variabel pelatihan (X2)

\section{Pengujian Hipotesis Penelitian}

a. Pengujian Hipotesis I: Pengaruh Supervisi Kepala Sekolah (X1) terhadap Kinerja Guru (Y)

Hipotesis pertama yang diuji dalam penelitian ini adalah "terdapat pengaruh yang signifikan antara supervisi kepala dengan variabel kinerja guru (Y). Selanjutnya diperoleh nilai signifikansi (sig) deviation from linearity self efficacy (X3) dengan kinerja guru (Y) adalah 0,257, nilai ini lebih besar dari 0,05. Maka dapat disimpulkan bahwa adanya hubungan yang linear secara signifikan antara variabel self efficacy (X3) dengan variabel kinerja guru (Y).

\section{c. Uji Multikolinieritas}

Pada kolom Variance Inflation Factor (VIF) diperoleh bahwa besarnya nilai VIF pada variabel supervisi kepala sekolah $\left(\mathrm{X}_{1}\right)$ sebesar 1,315, pelatihan $\left(\mathrm{X}_{2}\right)$ sebesar 2,720 , dan self efficacy $\left(\mathrm{X}_{3}\right)$ sebesar 2,583,. Besarnya nilai VIF dari masing-masing variabel menunjukkan lebih kecil dari 10. Hal ini menunjukkan tidak terjadi multikolinieritas diantara variabel bebasnya

sekolah $\left(\mathrm{X}_{1}\right)$ terhadap kinerja guru (Y)".Untuk pengujian hipotesis menggunakan analisis regresi dan korelasi sederhana. Hasil uji pengaruh variabel supervisi kepala sekolah dengan kinerja guru disajikan dalam tabel berikut ini.

\begin{tabular}{|c|c|c|c|c|c|}
\hline \multicolumn{2}{|c|}{ Coefficients $^{\mathbf{a}}$} & \multirow{2}{*}{ Sig. } \\
\hline \multirow{2}{*}{ Variabel } & \multicolumn{2}{|c|}{$\begin{array}{c}\text { Unstandardized } \\
\text { Coeff }\end{array}$} & $\begin{array}{c}\text { Standardized } \\
\text { Coeff }\end{array}$ & Beta & Std. \\
\cline { 2 - 5 } & Brror & 6.721 & & 5.785 & 0,000 \\
\hline $\begin{array}{c}\text { Supervisi kepala } \\
\text { sekolah }\end{array}$ & 0,511 & 0,074 & 0,638 & 6.888 & 0,000 \\
\hline a. Dependent Variabel: Kinerja Guru (Y) & & & \\
\hline
\end{tabular}


Berdasarkan di atas tentang uji $t_{\text {hitung }}$ Coefficient variabel supervisi kepala sekolah (X1) terhadap kinerja gurunjadi $\hat{\mathrm{Y}}=38.882+0,511 \mathrm{X} 1$. Nilai Coefficients supervisi kepala sekolah (X1) sebesar 0,511 . Hal ini mengandung arti bahwa setiap kenaikan supervisi kepala sekolah satu satuan maka kinerja guru juga akan naik sebesar 0,511 satu satuan. Berdasarkan uraian tersebut maka dapat disimpulkan terdapat pengaruh yang signifikan antara supervisi kepala sekolah $\left(\mathrm{X}_{1}\right)$ terhadap kinerja guru $(\mathrm{Y})$.

Selanjutnya untuk mengetahui besarnya pengaruh atau koefisien determinasi antara variabel supervisi kepala sekolah $\left(\mathrm{X}_{1}\right)$ terhadap kinerja guru (Y) disajikan dalam tabel berikut ini.

\begin{tabular}{lcc}
\hline Predictor & R & R Square \\
\hline Supervisi Kepala Sekolah & 0.638 & 0.407 \\
\hline
\end{tabular}

Dependent Variable: Kinerja_Guru

Pada tabel di atas, diperoleh $\mathrm{R}$ Square $\left(r^{2}\right)=0,407$ atau $40,7 \%$, artinya besar pengaruh supervisi kepala sekolah (X1) terhadap kinerja guru (Y) bimbingan konseling SMA kota Pekanbaru adalah $40,7 \%$, sedangkan sisanya $59,3 \%$

\section{b. Pengujian Hipotesis II: Pengaruh Pelatihan (X2) terhadap Kinerja Guru (Y)}

Hipotesis kedua yang diuji dalam penelitian ini adalah "terdapat pengaruh yang signifikan antara pelatihan $\left(\mathrm{X}_{2}\right)$ ditentukan oleh factor lain yang tidak menjadi bagian dari penelitian ini. Dengan demikian dapat disimpulkan, bahwa pengaruh variabel supervisi kepala sekolah (X1) terhadap kinerja guru (Y).

\begin{tabular}{|l|c|c|c|c|c|}
\hline \multirow{4}{*}{ Variabel } & \multicolumn{2}{|c|}{$\begin{array}{c}\text { Unstandardized } \\
\text { Coeff }\end{array}$} & $\begin{array}{c}\text { Standardized } \\
\text { Coeff }\end{array}$ & \multirow{2}{*}{ t } & \multirow{2}{*}{ Sig. } \\
\cline { 2 - 6 } & B & $\begin{array}{c}\text { Std. } \\
\text { Error }\end{array}$ & Beta & & \\
\hline (Constant) & 28.423 & 8.553 & & 3.323 & 0,001 \\
\hline Pelatihan & 0.722 & 0.109 & 0.624 & 6.633 & 0,000 \\
\hline a. Dependent Variabel: Kinerja Guru (Y) & & \\
\hline
\end{tabular}

Berdasarkan tabel di atas tentang uji $\mathrm{t}_{\text {hitung }}$ Coefficient variabel pelatihan (X2) terhadap kinerja guru (Y), diperoleh persamaan regresinya menjadi $\hat{Y}=$ 
$28.423+0,722$ X2. Nilai Coefficients pelatihan (X2) sebesar 0,722. Hal ini mengandung arti bahwa setiap kenaikan pelatihan satu satuan maka pelaksanaan kinerja guru juga akan naik sebesar 0,722 satu satuan. Berdasarkan uraian tersebut maka dapat disimpulkan terdapat pengaruh yang signifikan antara pelatihan $\left(\mathrm{X}_{2}\right)$ terhadap kinerja guru $(\mathrm{Y})$.

Selanjutnya untuk mengetahui besarnya pengaruh atau koefisien determinasi antara variabel pelatihan $\left(\mathrm{X}_{2}\right)$ terhadap kinerja guru $(\mathrm{Y})$ disajikan dalam tabel berikut ini.

\begin{tabular}{lcc}
\hline Predictor & R & R Square \\
\hline Pelatihan & 0.624 & 0.389 \\
\hline
\end{tabular}

Dependent Variable: Kinerja_Guru

Dari tabel di atas, diperoleh $\mathrm{R}$ Square $\left(r^{2}\right)=0,389$ atau $38,9 \%$, artinya besar pengaruh pelatihan (X2) terhadap kinerja guru (Y) bimbingan konseling SMA kota Pekanbaru adalah 38,9\%, sedangkan sisanya $71,1 \%$ ditentukan oleh faktor lain yang tidak menjadi bagian dari penelitian ini.

\section{c. Pengujian Hipotesis III: Self Efficacy (X3) terhadap Kinerja Guru (Y)}

\begin{tabular}{|l|c|c|c|c|c|}
\hline \multirow{2}{*}{ Variabel } & \multicolumn{7}{|c|}{$\begin{array}{c}\text { Coefficients } \\
\text { Unstandardized } \\
\text { Coeff }\end{array}$} & $\begin{array}{c}\text { Standardized } \\
\text { Coeff }\end{array}$ & \multirow{2}{*}{ t } & \multirow{2}{*}{ Sig. } \\
\cline { 2 - 5 } & B & $\begin{array}{c}\text { Std. } \\
\text { Error }\end{array}$ & Beta & & \\
\hline (Constant) & 21.138 & 6.601 & & 3.202 & 0,002 \\
\hline Self Efficacy & 0.733 & 0.076 & 0.760 & 9.702 & 0,000 \\
\hline \multicolumn{2}{|c|}{ a. Dependent Variabel: Kinerja Guru (Y) }
\end{tabular}


Berdasarkan tabel di atas tentang uji thitung Coefficient variabel pelatihan (X2) terhadap kinerja guru (Y), diperoleh persamaan regresinya menjadi $\hat{\mathrm{Y}}=$ $28.423+0,733$ X3 . Nilai Coefficients self efficacy (X3) sebesar 0,733. Hal ini mengandung arti bahwa setiap kenaikan self efficacy satu satuan maka pelaksanaan kinerja guru juga akan naik sebesar 0,733 satu satuan. Berdasarkan uraian tersebut maka dapat disimpulkan terdapat pengaruh yang signifikan antara self efficacy $\left(\mathrm{X}_{3}\right)$ terhadap kinerja guru (Y).

Selanjutnya untuk mengetahui besarnya pengaruh atau koefisien determinasi antara variabel self efficacy $\left(\mathrm{X}_{3}\right)$ terhadap kinerja guru $(\mathrm{Y})$ disajikan dalam tabel berikut ini.

\begin{tabular}{lcc}
\hline Predictor & R & R Square \\
\hline Pelatihan & 0.760 & 0.577 \\
\hline
\end{tabular}

Dependent Variable: Kinerja_Guru

Dari tabel di atas, diperoleh R Square $\left(\mathrm{r}^{2}\right)$ $=0,577$ atau $57.7 \%$, artinya besar pengaruh self efficacy (X3) $57.7 \%$, sedangkan sisanya $42.3 \%$ ditentukan oleh faktor lain yang tidak menjadi bagian dari penelitian ini.

\section{d. Pengujian Hipotesis IV: Pengaruh Supervisi Kepala Sekolah (X1), Pelatihan (X2), dan Self Efficacy (X3) terhadap Kinerja Guru (Y)}

Hipotesis keempat yang diuji dalam penelitian ini adalah "terdapat pengaruh yang signifikan antara supervisi kepala sekolah $\left(\mathrm{X}_{1}\right)$, pelatihan $\left(\mathrm{X}_{2}\right)$, dan self efficacy $\left(\mathrm{X}_{3}\right)$ terhadap kinerja guru(Y)".Untuk pengujian hipotesis menggunakan analisis regresi dan korelasi sederhana. Hasil uji pengaruh variabel supervisi kepala sekolah, pelatihan, dan self efficacy dengan kinerja guru disajikan dalam tabel berikut ini.

\begin{tabular}{|l|c|c|c|c|c|}
\hline \multirow{2}{*}{ Variabel } & \multicolumn{2}{|c|}{$\begin{array}{c}\text { Unstandardized } \\
\text { Coeff }\end{array}$} & $\begin{array}{c}\text { Standardized } \\
\text { Coeff }\end{array}$ & \multirow{2}{*}{ t } & \multirow{2}{*}{ Sig. } \\
\cline { 2 - 5 } & $\mathbf{B}$ & $\begin{array}{c}\text { Std. } \\
\text { Error }\end{array}$ & Beta & & \\
\hline (Constant) & 24.248 & 11.862 & & 2.044 & 0,045 \\
\hline Supervisi Kepala Sekolah & 0.226 & 0,098 & 0,244 & 2.313 & 0,024 \\
\hline Pelatihan & 0.244 & 0,104 & 0,249 & 2.348 & 0,022 \\
\hline Self Efficacy & 0.260 & 0.094 & 0.298 & 2.771 & 0.007 \\
\hline \multicolumn{7}{|c|}{ a. Dependent Variabel: Kinerja Guru (Y) } \\
\hline
\end{tabular}


Berdasarkan tabel variabel supervisi kepala sekolah (X1), pelatihan (X2), dan self efficacy (X3) terhadap kinerja guru (Y), sehingga persamaan regresinya menjadi $\hat{Y}=24.248+$ $0.226 \mathrm{X} 1+0.244 \mathrm{X} 2+0.260 \mathrm{X} 3$. Nilai Coefficients supervisi kepala sekolah (X1) sebesar 0.226. Hal ini mengandung arti bahwa setiap kenaikan supervisi kepala sekolah satu satuan maka kewajiban guru juga akan naik sebesar 0.226 satu satuan, dengan asumsi bahwa variabel bebas yang lain dari model regresi adalah tetap. Selanjutnya nilai Coefficients pelatihan (X2) sebesar 0.244 Hal ini mengandung arti bahwa setiap kenaikan pelatihan satu satuan maka variabel kinerja guru juga akan naik sebesar 0.244 satu satuan dengan asumsi bahwa variabel bebas yang lain dari model regresi adalah tetap. Selanjutnya nilai Coefficients self efficacy (X3) sebesar $0.260 \mathrm{Hal}$ ini mengandung arti bahwa setiap kenaikan self efficacy satu satuan maka variabel kinerja guru juga akan naik sebesar 0.260 satu satuan dengan asumsi bahwa variabel bebas yang lain dari model regresi adalah tetap.Dengan demikian maka dapat disimpulkan bahwa terdapat pengaruh yang siginifikan antara supervisi kepala sekolah $\left(\mathrm{X}_{1}\right)$, pelatihan $\left(\mathrm{X}_{2}\right)$, dan self efficacy $\left(\mathrm{X}_{2}\right)$ terhadap kinerja guru $(\mathrm{Y})$.

Selanjutnya untuk mengetahui besarnya pengaruh atau koefisien determinasi antara variabel supervisi kepala sekolah $\left(\mathrm{X}_{1}\right)$, pelatihan $\left(\mathrm{X}_{2}\right)$, dan self efficacy $\left(\mathrm{X}_{2}\right)$ terhadap kinerja guru (Y). disajikan dalam tabel berikut ini.

\begin{tabular}{|c|c|c|}
\hline Predictor & $\mathbf{R}$ & R Square \\
\hline $\begin{array}{c}\text { Supervisi_Kepala_Sekolah, Pelatihan, } \\
\text { Self_Efficacy }\end{array}$ & 0.534 & 0.285 \\
\hline
\end{tabular}

Dari tabel di atas, diperoleh $\mathrm{R}$ Square $\left(r^{2}\right)=0.285$ atau $28.5 \%$, artinya besar pengaruh supervisi kepala sekolah (X1), pelatihan (X2), dan self efficacy (X3) terhadap kinerja guru (Y) bimbingan konseling SMA kota Pekanbaru adalah $28.5 \%$, sedangkan sisanya $71.5 \%$ ditentukan oleh faktor lain yang tidak menjadi bagian dari penelitian ini.

\section{SIMPULAN}

Berdasarkan hasil penelitian yang telah dilaksanaka, analisis data, uji hipotesis dan pembahasan hasil penelitian, dapat ditarik kesimpulan sebagai berikut:

1)Terdapat pengaruh yang positif dan signifikan antara supervisi kepala sekolah
(X1) dengan kinerja guru (Y) bimbingan konseling SMA Kota Pekanbaru. Supervisi kepala sekolah secara nyata turut menentukan dan memberikan pengaruh terhadap kinerja guru. Artinya kinerja guru dapat ditingatkan melalui supervisi kepala sekolah yang baik. 2)Terdapat pengaruh yang positif dan siginfikan antara pelatihan (X2) dengan kinerja guru (Y) bimbingan konseling SMA Kota Pekanbaru. Pelatihan dapat juga menentukan dan memberikan pengaruh terhadap kinerja guru. Artinya kinerja guru (Y) bimbingan konseling SMA Kota Pekanbaru dapat meningkat dengan semakin seringnya pelatihan yang diikuti oleh guru. 3)Terdapat pengaruh yang positif dan signifikan antara self 
efficacy (X3) dengan kinerja guru (Y) bimbingan konseling SMA Kota Pekanbaru. Self efficacy dapat juga menentukan dan memberikan pengaruh terhadap kinerja guru. Artinya kinerja guru bimbingan konseling SMA Kota Pekanbaru dapat juga meningkat seiring dengan self efficacy yang baik. 4)Terdapat pengaruh yang positif dan signifikan secara simultan antara supervisi kepala sekolah, pelatihan, dan self efficacy terhadap kinerja guru bimbingan konseling SMA Kota Pekanbaru.

\section{UCAPAN TERIMA KASIH}

Pada akhirnya, penulis menyadari bahwaartikel ini tidak akan selesai tanpa dukungan dari rekan-rekan majelis guru SMA Cendana Pekanbaru atas segala bantuan dan dukungan yang telah diberikan.

\section{DAFTAR PUSTAKA}

Ahmad Maulid, 2016. Pengaruh Supervisi Kepala Sekolah dan Pengembangan Tenaga Pendidik Terhadap Kinerja Guru Madrasah Aliyah Swasta Di Kabupaten Limah Puluh Kota. Kepala Madrasah Ma'arif As-sa'diyah Payakumbuh. Jurnal Manajemen, kepemimpinan, dan supervisi.

Asifa Sopandi, 2019. Pengaruh Efikasi Diri dan Keterlibatan Kerja terhadap Kinerja Guru. Universitas Pendidikan Indonesia.

Atik Novitasari, dkk, 2012. Pengaruh Kepemimpinan Kepala Sekolah, Lingkungan Kerja, Pendidikan, dan Pelatihan terhadap Kinerja Guru. economic Education Analysis

Journal. Universitas negeri

Semarang. ISSN 2252-6544.

Bandura, Albert, 2009. Self efficacy in Changing Societies. Cambridge University Press. New York.

Bandura, Albert, 1997. Self efficacy The Execise of Control. W.H. freeman and Company. New York.

Edi Rismawan, 2015. Pengaruh Supervisi Kepala Sekolah dan Motivasi Berprestasi Guru terhadap Kinerja Mengajar Guru. Jurnal Administrasi Pendidikan Vol. XXII No. 1 April 2015.

Edi Supriyono, 2014. Pengaruh Supervisi Kepala Sekolah terhadap Kinerja Guru SD SeKecamatan Sewon Bantul Yogyakarta.

Farida Hanun, 2013. Pengaruh Efikasi Diri, iklim kerja dan motivasi berprestasi terhadap kinerja kepala madrasah (survey di madrasah ibtidaiyah kota Bekasi). Puslitbang Pendidikan Agama dan Keagamaan.

Indri Novayanti gala, dkk, 2017. Pengaruh Pelatihan dan Motivasi Kerja terhadap Kinerja Mengajar Guru IPA di SMP se-Kota Poso. eJurnal Mitra Sains, Volume 5 Nomor 2, April 2017 hlm 58-66. ISSN: 2302-2027. Poso

Jahangir.S.F, 2012. In Service Training: A Contributory Factor Influencing Teacher's Performance. International Journal of Academic Research in Progresive Education and Development. 1(1):32-37 
Jusmaliani, 2014. Pengelolaan Sumber Daya Insani. Jakarta: Bumi Aksara

Dewi Herawaty, 2016. Pengaruh Kecerdasan Emosional, Partisipasi Guru dalam Forum Ilmiah, Keyakinan Diri dan Motivasi Kerja terhadap Kinerja Guru Matematika. Jurnal Review Pembelajaran Matematika.

Leni Oktavia, 2018. Pengaruh Supervisi Kepala Sekolah dan Self efficacy terhadap Kinerja Guru dengan Motivasi sebagai variabel Intervening pada SMK Bina Karya 2 Karanganyar.

Gerson Salomo Kolondam, 2017. Pengaruh Kepemimpinan, Self efficacy dan Komitmen Organisasi Terhadap Kinerja Guru di SMP Negeri 7 Manado.

Kurniadin, Didin, and Imam Machali. 2016. Manajemen Pendidikan (Konsep \& Prinsip Pengelolaan Pendidikan). Jogjakarta: Ar-Ruzz Media.

Anwar Prabu Mangkunegara, 2009. Manajemen Sumber Daya Manusia Perusahaan. Bandung: PT Remaja Rosdakarya.
Muhammad Busro, 2018. Teori-teori Manajemen Sumber Daya Manusia. Edisi Pertama. Jakarta: Prenada Media.

Mulyasa, E. 2012. Manajemen dan Kepemimpinan Kepala Sekolah. Jakarta: PT Bumi Aksara.

Muhammad Nisfiannoor, 2009. Pendekatan Statistika Modern Untuk Ilmu Sosial. Jakarta: Salemba Humanika.

Ngalim Purwanto, 2019. Administrasi dan Supervisi Pendidikan. Bandung: PT Remaja Rosdakarya

Slameto, dkk. 2017. Peningkatan Kinerja Guru melalui Pelatihan beserta Faktor Penentunya. Jurnal Pendidikan Ilmu Sosial, Vol. 27 No. 2 Desember 2017.

Sugiyono. 2018. Metode Penelitian Manajemen. $\quad$ Bandung: $\mathrm{CV}$. Alfabeta.

Supardi, 2016. Kinerja Guru. Jakarta: PT RajaGrafindo Persada.

Wibowo, 2011. Manajemen Kinerja. RajaGrafindo Persada. 